\title{
Tomasz Padło
}

Uniwersytet Pedagogiczny

im. Komisji Edukacji Narodowej

w Krakowie

\section{Granice państwowe jako atrakcja turystyczna i szansa rozwoju obszarów peryferyjnych}

\section{State borders as a tourist attraction and an opportunity for the development of peripheral areas}

\begin{abstract}
Streszczenie
Badania atrakcyjności turystycznej granic państwowych mają niedługą tradycję i skupiają się raczej na obszarze pogranicza niż na nich samych. Sama granica, traktowana jako linia oddzielająca dwa kraje, w wielu częściach świata przyciąga turystów, choć określenie jej wpływu na turystykę regionu jest często utrudnione z uwagi na fakt, że jej „doświadczanie” jest zazwyczaj jedynie elementem szerszej aktywności turystycznej. Potencjał turystyczny granic - szczególnie ich silnie umocnionych odcinków oraz tych mających nietypowy przebieg, np. trójstyków i enklaw - wydaje się niewykorzystany. Tymczasem przykłady DMZ w Korei czy przejścia granicznego Wagah na granicy indyjsko-pakistańskiej pokazują, że wykorzystanie turystyczne granicy może być istotnym elementem rozwoju regionu. Szczególnie atrakcyjne wydają się granice pełniące wyraźne funkcje rozdzielające odmienne systemy gospodarcze bądź cywilizacje. Niewykorzystane w tym kontekście są granice zewnętrzne Unii Europejskiej, dawna żelazna kurtyna oraz granice byłego Związku Radzieckiego, które na wielu odcinkach do dzisiaj zachowały cechy minionego systemu. Wraz z rozwojem alternatywnych form turystyki wykorzystanie atrakcyjności granic może stanowić czynnik rozwoju obszarów peryferyjnych.
\end{abstract}

\begin{abstract}
Researching the tourism attractiveness of state borders does not have a very long tradition and focuses more on the borderlands rather than the actual border itself. The border, considered to be a dividing line between two countries, attracts tourists in many parts of the world, but determining its impact on the tourism of the region is often difficult due to the fact that its "experience" is usually only part of a wider range of tourism activities. The tourism potential of state borders, especially the stronger sections and those with interesting routes, e.g. triplexes and enclaves, seems unused, while examples of the DMZ in Korea or the Wagah border crossing on the border between India and Pakistan show that the use of the border may be an important element of the development of a region. The boundaries performing distinct functions, separating different economic systems, or civilizations, seem to be particularly attractive. In this context, the external borders of the European Union are unused; the former Iron Curtain and the borders of the former Soviet Union, which in many places still retain features of the previous system. The attractiveness of the borders may have an impact for the development of peripheral areas with the development of alternative forms of tourism.
\end{abstract}

Słowa kluczowe: atrakcyjność; granica; pogranicze; turyzm

Keywords: attractiveness; border; borderland; tourism 


\section{Wstęp}

Granica w ujęciu politycznym stanowi zazwyczaj barierę dla aktywności przestrzennej, ale równocześnie jej przekroczenie powoduje u podróżnego poczucie zmiany, opuszczenia jednego terytorium i wkroczenia na inny obszar. Przekraczanie granic jest integralną częścią podróżowania, niemniej granica sama w sobie stanowi w powszechnym odczuciu pewną ograniczającą konieczność. W dobie zacieśniania współpracy w ramach Unii Europejskiej jedną z bardziej obrazowych korzyści integracji, wymienianą często w dyskursie publicznym, jest wdrożenie układu z Schengen znoszącego m.in. kontrolę graniczną. W tej sytuacji granica przestaje być barierą w sensie fizycznym. W tym kontekście celowe wydaje się zadanie pytania o zasadność zajmowania się tezą zawartą w tytule artykułu, skoro granice polityczne, szczególnie jej funkcje ograniczające i kontrolujące, tak usilnie próbuje się znieść. Odpowiedzią niech będzie cytat wskazujący, że już samo przekraczanie granicy może być jedną z motywacji przyjazdu do konkretnego regionu: ,[...] na odcinku kilku metrów przechodzimy z jednego geograficznego podmiotu do innego, który wygląda dokładnie tak samo, ale jest wyjątkowy, ma inną nazwę, jest na wiele sposobów zupełnie odrębnym światem od tego, który właśnie opuściliśmy... To poczucie przechodzenia z jednego świata w inny zachwyca i fascynuje" (Ryden, 1993: 1). Ta odrębność światów jest w wielu przypadkach przerysowana, nie ulega jednak wątpliwości, że fascynacja, o której pisze Ryden, często nam w tym procesie towarzyszy. Świadczy o niej choćby mnogość zdjęć wykonywanych na granicach przy znakach i słupkach granicznych oraz pozostałych elementach infrastruktury z nią związanych. „Przekraczanie granicy”, które w sensie dosłownym oznacza właśnie to przechodzenie ,z jednego geograficznego podmiotu do innego”, w języku ma znaczenie szersze, nierzadko odnoszące się do transcendencji, co podkreśla znaczenie tej czynności. Samo przemierzanie szlaków karpackich przebiegających wzdłuż polsko-słowackiej granicy dla wielu turystów było podwójnie ekscytujące z racji możliwości postawienia stopy po drugiej stronie granicy, a pierwsze wyjazdy zagraniczne - z niezwykle rozbudowaną wyjazdową procedurą biurokratyczną - wyraźnie podkreślały wyjątkowość tego niecodziennego procesu.

Celem artykułu, opierającego się na wspomnianym fenomenie, jest wskazanie możliwości rozwoju funkcji turystycznych wykorzystujących granice państwowe. Granice są wprawdzie obiektem licznych opracowań geograficznych, również w ramach geografii turyzmu, jednak ich atrakcyjność umożliwiająca rozwój funkcji turystycznej dotyczy zazwyczaj obszaru szeroko pojętego pogranicza. Tymczasem przedmiotem pracy jest granica państwowa traktowana właśnie jako linia, względnie pas ziemi, oddzielająca od siebie terytoria dwóch państw. Takie określenie celu pozwala zadać pytania badawcze o stosowane praktyki w wykorzystaniu granicy do rozwoju turystyki, o charakter granicy temu rozwojowi sprzyjający oraz możliwości wykorzystania tych praktyk w polskich warunkach. Dla osiągnięcia celu przeprowadzono analizę wykorzystującą metody jakościowe. Przestudiowano przypadki wykorzystania granicy w celach turystycznych w różnych częściach świata oraz skonfrontowano je z potencjalną atrakcyjnością granic europejskich, szczególnie polskich. Posłużono się w tym m.in. metodami humanistycznymi zaproponowanymi przez Squire’a (1994): analizą treści przewodników turystycznych, map i programów wycieczek. W badaniach użyto również opisu wyjaśniającego, opartego na metodzie dedukcyjnej. Wsparciem umożliwiającym osiągnięcie celu były również obserwacje poczynione w trakcie badań terenowych.

\section{Granica jako tlo}

Już w najoczywistszych znaczeniach semantycznych granica odnosi się do krańca czegoś, nosi w swojej nazwie ograniczenie przestrzeni. Szczególnie silna w tym kontekście jest granica państwowa, którą definiuje choćby Ustawa z dn. 12 października 1990 r. o ochronie granic państwowych. 
Artykuł 1 ustawy brzmi: „Granicą Rzeczypospolitej Polskiej, zwaną dalej »granicą państwową«, jest powierzchnia pionowa przechodząca przez linię graniczną, oddzielająca terytorium państwa polskiego od terytoriów innych państw i od morza pełnego. Granica państwowa rozgranicza również przestrzeń powietrzną, wody i wnętrze ziemi” (Dz.U. 1990 nr 78, poz. 461). Podobną definicję, wybiegającą oczywiście poza obszar RP, podają Baczwarow i Suliborski, zastępując powierzchnię pionową „wyimaginowaną kurtyną” (2002: 72), czy Otok uwzględniający dodatkowo w swojej definicji obszary ograniczone granicą, a niemające niczyjej suwerenności (2009: 80). Ten specyficzny charakter granicy państwowej, polegający na wyraźnym „odgrodzeniu” jednego terytorium od innego, sprawia, że jest jednym z ważnych obiektów badań w geografii politycznej (Redclift, 2006; Prescott, 1965, 1987; Sobczyński, 2006 za: Bańskim, 2010). Trzeba jednak pamiętać, że sama granica przyjmuje częściej charakter narzędzia badawczego niż przedmiotu badań, które to narzędzie koncentruje się częściej na terytoriach nią ograniczonych niż na niej samej (Bański, 2010). Tymczasem, mimo liniowego charakteru, jej znaczenie w geografii jest dużo szersze i obejmuje m.in. geografię turyzmu, mimo że pozostaje w jej bocznym, niedocenianym wciąż nurcie, którego rola, a tym samym rola granic, systematycznie rośnie (Timothy, 2000). Mimo że turystyka oparta o granicę państwową jest obiektem licznych opracowań, rzadko dotyczy jej bezpośrednio. W polskiej literaturze geograficznej zajmowano się szeroko współpracą transgraniczną w różnych skalach przestrzennych (m.in.: Kitowski, 1996, 1998, 2006; Mync, Szul, 1999; Heffner, 2002; Mogiła i in., 2011). Komornicki (1999) w swojej pracy poświęconej granicom analizował m.in. ruch graniczny, ale potraktował je głównie jako bariery. Współpraca transgraniczna w oparciu o trójstyki granic była natomiast przedmiotem zainteresowania Kałuskiego (2006), który jednak nie koncentrował się na ich atrakcyjności turystycznej. Tematyka wpływu granic państwowych na rozwój turystyki była znacznie rzadziej podejmowana. Można tutaj jedynie wymienić badania Kałuskiego (1993), Potockiego na pograniczu polsko-czeskim (2009) czy prace zbiorowe pod redakcją Bilińskiego i Sawaryna (2003) oraz IGiPZPAN dotyczącą pogranicza polsko-słowackiego (Więckowski i in., 2012). Niewątpliwie najpełniejszym opracowaniem na temat funkcji turystycznych granic jest monografia Więckowskiego (2010), który jednak - podobnie jak inni autorzy - skoncentrował się głównie na obszarze pogranicza, sygnalizując jedynie atrakcyjność samej granicy. Także literatura zagraniczna, bogata w prace na temat współpracy transgranicznej, również w sferze turystyki pomija kwestie samej granicy, koncentrując się bardziej na obszarach przyległych (Więckowski, 2010). Mimo że w licznych opracowaniach podkreśla się istotną rolę turystyki dla rozwojów obszarów pogranicza (Eriksson, 1979; Zhao, 1994; Paasi, Raivo, 1998; Timothy, 2000a), nieliczne są opracowania koncentrujące się na samej linii granicy. Wśród tych niewielu badaczy podejmujących tę tematykę należy wymienić przede wszystkim Timothy’ego (1995; 2000a; 2000b), którego prace będą jeszcze przywoływane.

W języku polskim określenie granica jest dość szerokie i nie uwidacznia choćby różnicy między granicą wyznaczoną w głównej mierze przez naturę (ang. frontier) a granicą wyznaczoną przez człowieka, odnoszącą się m.in. do dzisiejszego podziału politycznego świata (ang. boundary) (Blacksell, 2008). Tymczasem fizycznym ograniczeniem w rozwoju przestrzennym społeczeństw i państw budowanych w oparciu o te społeczeństwa były bariery naturalne, rozumiane właśnie jako frontier, występujące w postaci pasm górskich, rzek, mokradeł, puszcz, pustyni itd. - choć paradoksalnie niektóre z tych barier, jak np. rzeki, pełniły czy pełnią czasem funkcję łączącą (Rykiel, 2006). Dzisiaj obszary te często stanowią atrakcję turystyczną dzięki ich morfologicznym atrybutom lub relatywnie późnemu zagospodarowaniu, sprzyjającemu zachowaniu pierwotnego środowiska. Powoduje to, że obecnie funkcjonuje na świecie 227 transgranicznych obszarów chronionych, w tym 82 w Europie (Lysenko i in., 2007). Można 
tutaj podać przykład Pirenejów stanowiących granicę francusko-hiszpańską, a obejmujących ochroną m.in. obszar Pyrenees-Mont Perdu, wpisany na Listę światowego dziedzictwa UNE$S C O$, parki narodowe Argentera i Mercantour na alpejskim pograniczu francusko-włoskim, dolinę dolnej Odry czy Tatry w swojej polskiej i słowackiej części. Granica państwowa na tych obszarach nie decyduje jednak o atrakcyjności tych terenów, a jedynie je wykorzystuje, często stanowiąc wręcz barierę dla rozwoju turystyki m.in. przez ograniczanie możliwości przemieszczania się, jak to mam miejsce na pograniczu albańsko-macedońskim, serbsko-bułgarskim czy do niedawna na karpackich oraz sudeckich odcinkach pogranicza polsko-czechosłowackiego.

Obszary graniczne wielu państw cechuje pewien zespół korzyści i przewag wykorzystywanych w różnych dziedzinach gospodarki i często sprzyjających rozwojowi turystyki. Sama turystyka graniczna, według Timothyego i Walla (2001), może być badana co najmniej z dwóch perspektyw przestrzennych: turystyki, która zawdzięcza swoje istnienie granicy, ale nie koncentruje się bezpośrednio na niej, oraz turystyki skoncentrowanej na samej granicy. Timothy (2000) w ramach pierwszego typu wymienia m.in.: prostytucję, hazard, turystykę alkoholową czy turystykę zakupową, które szczególnie dynamicznie rozwijają się na wielu obszarach pogranicza dzięki odmiennym uregulowaniom prawnym i podatkowym lub po prostu przez zróżnicowany poziom rozwoju gospodarczego. Przykładem obszarów wzmożonej koncentracji prostytucji jest więc zarówno południowa część pogranicza amerykańsko-meksykańskiego, jak i wschodnia część pogranicza niemiecko-czeskiego, z poczesną pozycją miasta Cheb na mapie europejskich usług seksualnych (Boyes, Cywiński, 2003). Hazard stał się impulsem rozwojowym Utah dzięki liberalnemu prawu, pozwala też się rozwijać Macau, zachowującemu wyjątkowy status nawet po przyłączenia do Chin, czy egipskiej Tabie, korzystającej z bliskości Izraela i masowej turystyki w tamtejszym Eljacie (Felsenstein, Freeman, 2002). Turystyka alkoholowa to domena z jednej strony stref wolnocłowych, czego wyraz dają m.in. miłośnicy rejsów na bałtyckich promach, z drugiej - obszarów o zróżnicowanym obciążeniu podatkowym i akcyzowym produktów spirytusowych, czego efekt do niedawna obserwowaliśmy np. wzdłuż południowej granicy Polski. W końcu turystyka zakupowa, której rozwojowi sprzyjają m.in. zróżnicowana polityka podatkowa, korzystny kurs walutowy, różnorodny asortyment czy bardziej elastyczny czas pracy. Szczególnym przykładem są tutaj np. pogranicze szwedzko-norweskie, luksembursko-belgijskie czy niemiecko-szwajcarskie. Do wymienionych typów turystyki granicznej, zaproponowanych przez Timothy’ego, można jeszcze dodać np. turystykę narkotykową, której przykład stanowi od lat Holandia czy Maroko (szczególnie Szafszawan w górach Rif), a do których dołączają kolejne stany USA i Urugwaj.

Pograniczny charakter wymienionych rodzajów turystyki wynika z bariery odległości. Silnie zogniskowane potrzeby nie wymagają rozwoju usług komplementarnych, dlatego odległość od granicy jest głównym czynnikiem lokalizacyjnym. Jednak - podobnie jak w odniesieniu do granic naturalnych - również w tym przypadku granica wprawdzie stwarza pewne możliwości rozwoju turystyki przez kreowanie społecznego i ekonomicznego tła dla tego rodzaju działalności, ale sama w sobie atrakcją nie jest.

\section{Granica jako podmiot}

Początki turystyki masowej, z powodu barier transportowych, wysokich kosztów czy ograniczeń czasowych, kierowały rzesze turystów w stronę ośrodków miejskich. W ciągu ostatnich dekad, wraz z ograniczeniem wymienionych barier, aktywność turystyczna zaczęła obejmować obszary peryferyjne (Butler, 2002). Tereny pogranicza, z całym bagażem ograniczeń utrudniających rozwój turystyki, zaczęły być dla turystów coraz atrakcyjniejsze. Sama granica, w jej rozumieniu jako linii oddzielającej dwa terytoria, zaczęła stanowić cel aktywności podróżnych niezależnie od wspomnianych wyżej impulsów rozwoju turystyki na obszarach pogranicza. 
Spektakularnym przykładem atrakcyjności granic są granice reliktowe, które dziś już nie istnieją, ale które w przeszłości stanowiły ważną granicę polityczną. Najbardziej znanymi przykładami są Wielki Mur Chiński, Mur Hadriana i mur berliński. Nie jest przypadkiem, że każda z wymienionych granic miała postać muru. Ich atrakcyjność turystyczna wynika bowiem z istotnej funkcji rozdzielającej. W każdym wypadku mieliśmy do czynienia ze swoistym „,miejscem spotkań" odrębnych cywilizacji, których relacje oparte na konflikcie wymagały stworzenia wyraźnej bariery zapobiegającej przenikaniu. Mur Hadriana wyznaczający w II w n.e. północny zasięg wpływów Cesarstwa Rzymskiego został wpisany w 1987 r. na Listę światowego dziedzictwa kultury UNESCO. W tym samym roku umieszczono na niej Wielki Mur Chiński. Oba miały być zaporą dla najeźdźców z Północy, oba z funkcji nie do końca się wywiązały, ale pozostają charakterystycznym świadectwem swoich epok. Z kolei mur berliński, stanowiący najbardziej charakterystyczny element kontaktu XX-wiecznych imperiów, pozostaje jedną z głównych atrakcji turystycznych niemieckiej stolicy (Light, 2000), czego wyrazem są nie tylko liczne muzea i ekspozycje poświęcone jego historii, ale może przede wszystkim szereg reliktów i instalacji aktywnie współtworzących tkankę miasta (ryc. 1).

Ryc. 1. Mur berliński stanowi istotny element symboliczny miasta

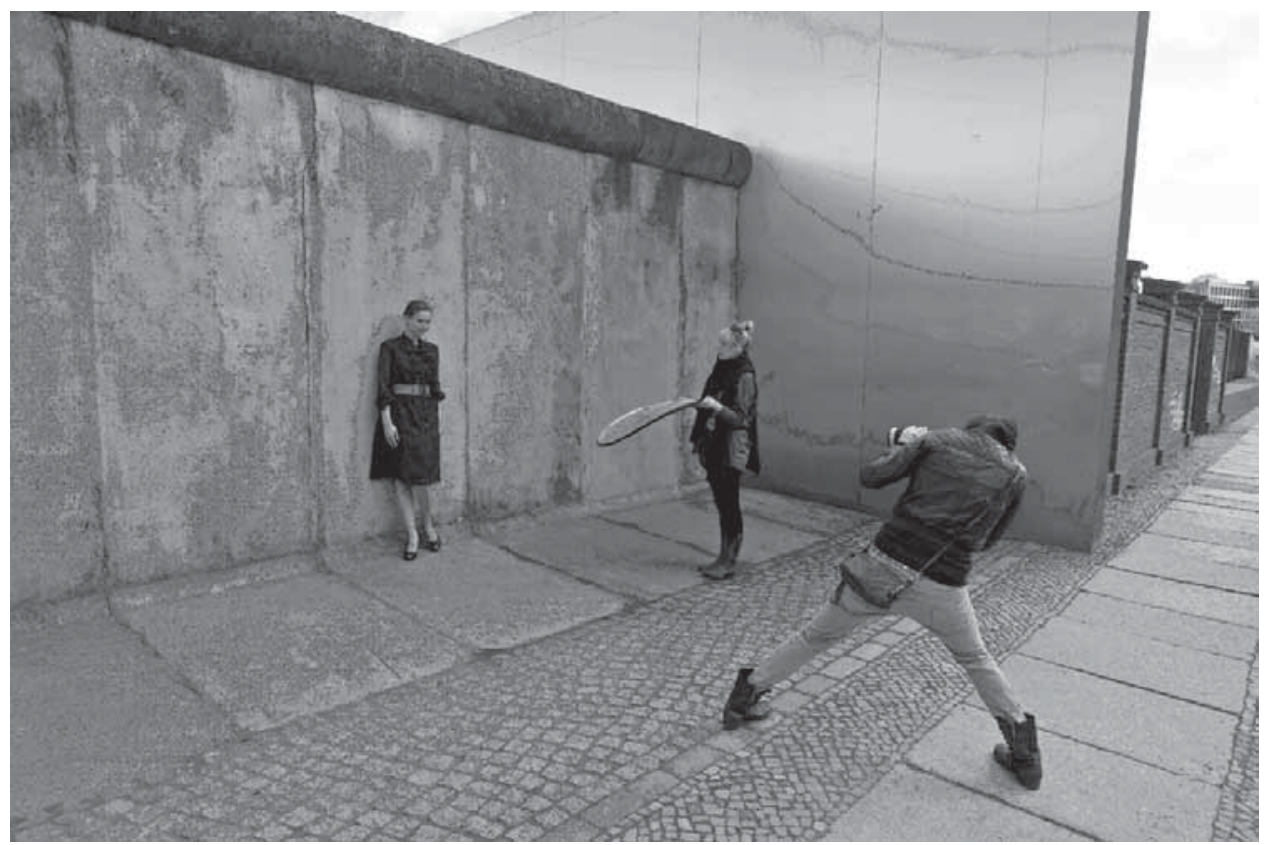

Źródło: fotografia autora.

Wciąż istniejące granice mają, zdawałoby się, ograniczone możliwości przyciągania turystów - chociażby z racji konfliktu między służbą ochroną granicy a chętnymi do jej oglądania, szczególnie jeśli weźmiemy pod uwagę, że obszary przygraniczne często objęte są obostrzeniami dotyczącymi poruszania się w nich czy fotografowania. $\mathrm{Z}$ drugiej strony granice łatwo dostępne dla turystów wydają się dla nich mniej atrakcyjne. Łatwiej o fascynację granicą pełniącą wyraźną funkcję rozróżniającą, za czym często idzie charakter samej granicy, próbującej fizycznie odseparować te odmienne światy. Trudniej o budowanie produktu turystycznego wykorzystującego fascynację granicą w przypadku państw należących do strefy Schengen, w której usunięto z krajobrazu fizyczne bariery, tym samym ograniczając możliwości ,przeżywania" granicy. 
Prawdopodobnie najchętniej odwiedzaną granicą dla samej granicy jest strefa zdemilitaryzowana (DMZ) pomiędzy Koreą Południową a KRLD. Tylko w 2009 r. odwiedziło ją ponad 6 mln turystów (Lee, Kang, 2013). Wokół strefy udostępniono dla zwiedzających szereg obiektów, m.in. tunele, obserwatoria, stację kolejową Dorasan czy wioskę Panmundżom, będącą jedynym punktem kontaktu oficjeli z obu krajów. Dodatkowo brak działalności ludzkiej w tej strefie przyczynił się do ekspansji wielu rzadkich gatunków flory i fauny, w tym blisko 1600 gatunków roślin, 201 gatunków ptaków, 52 gatunki ssaków oraz 106 gatunków ryb (Korea National Tourism Organization, 2004). Jednak to nie przyroda, a przede wszystkim symboliczny charakter granicy oddzielającej odmienne systemy polityczne - będące dodatkowo do niedawna symbolem zimnowojennego podziału świata - przyciąga tak wielu turystów.

Więcej szczęścia w dążeniu do zjednoczenia kraju mieli Wietnamczycy - mimo to pamięć podziału kraju z czasów wojny wciąż jest żywa i znajduje swoje odbicie również w wykorzystaniu dawnej strefy demarkacyjnej do celów turystycznych. Występuje to jednak w szerszym kontekście dynamicznie rozwijającej się turystyki wojennej, o czym pisze Didier Lauras we wstępie do projektu fotograficznego Patricka Zachmanna Distro - War Tourism In Vietnam (www.magnumphotos.com/C.aspxVP3=SearchResult\&ALID=2TYRYDA8TPED).

Równie rozpoznawalną granicą konfliktu jest ta indyjsko-pakistańska. Trudne relacje historyczne między tymi państwami konserwuje wciąż niezakończony konflikt o Kaszmir. Mimo że oba kraje szachują się wzajemnie swoim arsenałem jądrowym, demonstracja sił w położonym pomiędzy Lahore i Amritsar Wagah - jednym z dwóch czynnym przejść granicznych na liczącej ok. 3000 km długości granicy - wydaje się mieć mniej poważny charakter. Opuszczanie flag, odbywające się każdego dnia na ok. 2 godziny przed zachodem słońca, przyciąga codziennie dziesiątki tysięcy turystów (Mehdi, 2005), którzy są świadkami tego niezwykłego wydarzenia:

„Tłumy zbierają się po obu stronach bramy, klaszcząc i krzycząc «Pakistan Zindabad!» i «Jai Hind!». Nabieram powietrza jakby w oczekiwaniu na rozpoczęcie meczu i faktycznie po zamknięciu bramy rozpoczyna się rywalizacja między dwoma drużynami. Ta w kolorze khaki to indyjskie siły ochrony pogranicza. Pakistańscy Rangersi z kolei lśnią czernią swoich strojów. Każdy z graczy ma ponad $180 \mathrm{~cm}$ wzrostu, budzący przerażenie zarost na twarzy oraz imponujący turban na głowie.

Oficjalnym celem ceremonii jest jednoczesne opuszczenie flag przed zachodem słońca, ale gdy wartownicy z obu stron zaczynają tańczyć agresywne, bezdotykowe tango, prawdziwy cel ceremonii staje się jasny: danie upustu głębokiej wrogości i wzajemnej niechęci między Indiami i Pakistanem. Niezamierzonym efektem ubocznym ceremonii jest zdemaskowane podobieństwo między obu stronami” (Jacobs, 2012).

Przytoczone dwa przykłady wykorzystania potencjału granic jako atrakcji turystycznej są prawdopodobnie najbardziej spektakularne, czego wyrazem są miliony turystów co roku je odwiedzających. Cechą obu jest napięta sytuacja między sąsiadującymi państwami, przejawiająca się w ograniczonych relacjach międzynarodowych i, zazwyczaj, w olbrzymich różnicach kulturowych bądź/i ekonomicznych. W obu przypadkach przyciąga zatem wyartykułowana we wstępie słowami K.C. Rydena odmienność obu stron, mimo że w żadnym z nich nie dochodzi do fizycznego przekroczenia granicy. Rzekome podobieństwo obu stron konfliktu, stwierdzone przez Jacobsa, o tyle mija się z prawdą, że granica indyjsko-pakistańska jest więcej niż tylko granicą państwową, ścierają się bowiem na niej dwie z zaproponowanych przez Huntingtona cywilizacji: hinduistyczna i islamska (Huntington, 2007). Obie omówione granice egzemplifikują więc dwa typy zróżnicowania współczesnego świata: ekonomiczny, z silną podbudową ideologiczną w przypadku obu Korei, oraz cywilizacyjny. Sposób ograniczenia przestrzeni w oparciu o te dwa rodzaje konfliktów sugeruje, że właśnie na stykach szczególnie dużych konfliktów potencjał rozwoju turystyki bazującej na granicach jest największy. 
Timothy (2000) zwraca też uwagę na inną cechę granic, przyciągającą uwagę turystów, mianowicie ich niecodzienny przebieg. Wymienia w tej grupie miejsca połączenia trzech granic, tzw. trójstyki, oraz enklawy. Miejsca styku trzech granic są na świecie powszechne, choć nie zawsze łatwo dostępne z racji ich peryferyjnego charakteru. W różny sposób ich potencjał jest też wykorzystywany. Zazwyczaj ogranicza się on do podkreślenia nietypowości miejsca przez umieszczenie pamiątkowego obelisku (np. granice czesko-austriacko-niemiecka, fińsko-norwesko-szwedzka) lub tablicy informacyjnej (np. granica polsko-litewsko-rosyjska). Szczególnym przypadkiem jest punkt styku czterech granic stanowych w USA: Arizony, Kolorado, Nowego Meksyku i Utah. Tak niecodzienne miejsce spowodowało rozwinięcie w jego otoczeniu grupy usług turystycznych w ramach tzw. Four Corners Monument. Stany Zjednoczone są jednak krajem szczególnym pod względem wykorzystania granic, zwłaszcza na pograniczu kanadyjskim. Dość wspomnieć o The Haskell Free Library and Opera House na granicy Quebec i Vermont czy Peace Arch oraz International Peace Garden na granicy Waszyngtonu z Kolumbią Brytyjską, przyciągającym 200 tys. turystów rocznie.

Również enklawy - których jest na świecie 262, w tym 17 tzw. realnych (true enclaves) (Vinokurov, 2007) - z racji swojego niecodziennego statusu politycznego mogą stanowić interesującą destynację turystyczną. Przykładem są włoskie Campione otoczone terytorium Szwajcarii czy hiszpańska Llivia położona wewnątrz terytorium Francji (Timothy, 1996). Jednak najlepszym przykładem wykorzystania potencjału enklawy z podmiotową rolą jej granic jest niewątpliwie belgijskie Baarle Hertog - zespół 22 enklaw leżących na terytorium Holandii. Skrupulatnie wyznaczona granica stanowi dużą atrakcję turystyczną, szczególnie że na swojej drodze napotyka szereg obiektów (ryc. 2). Skomplikowana dla mieszkańców kwestia przynależności państwowej, obejmująca m.in. odmienną politykę podatkową, rekompensowana jest istotnym rozwojem usług turystycznych bazujących niemal wyłącznie na tej niedogodności.

Ryc. 2. Budowanie produktu turystycznego w oparciu o nietypowy przebieg granicy w enklawie Baarle Hertog

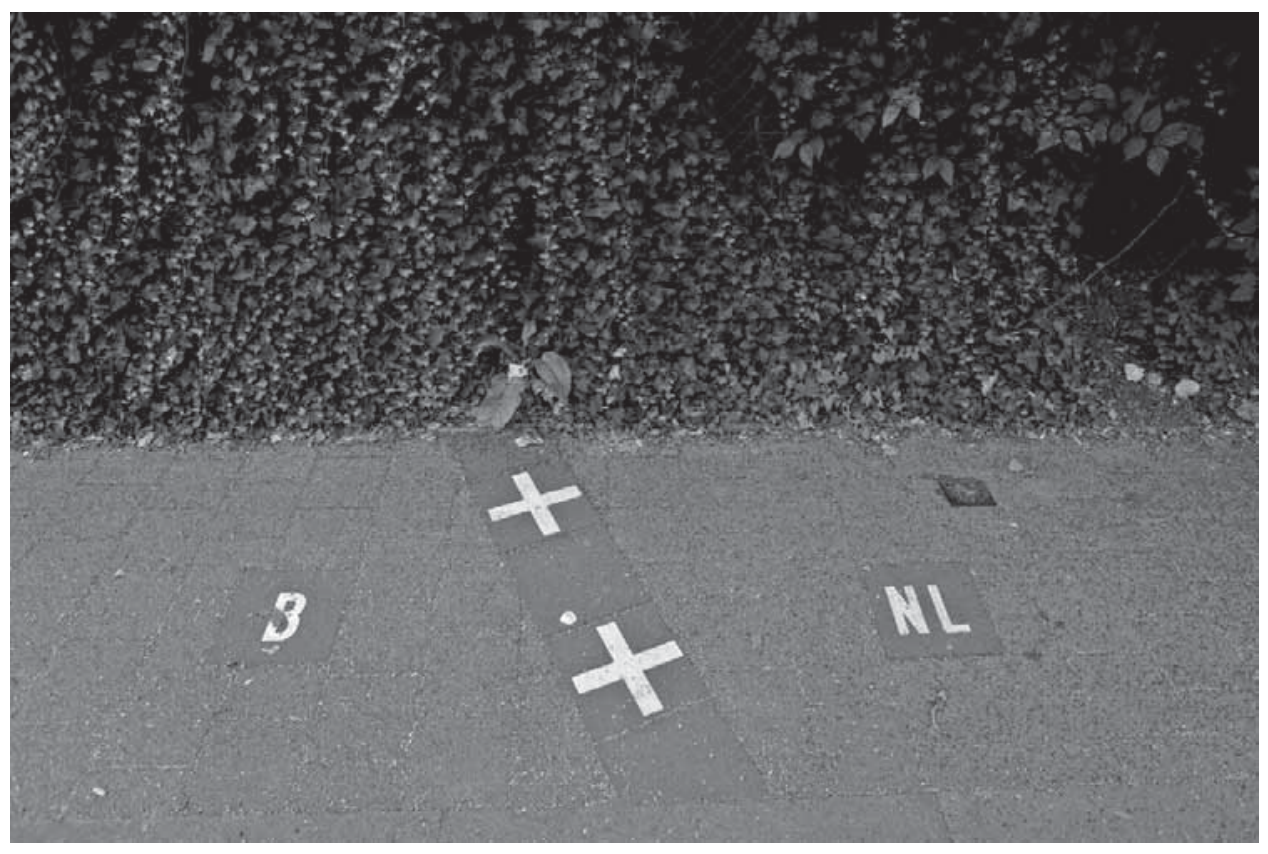

Źródło: fotografia autora. 


\section{Granica jako potencjal}

Europa stanowi swoistą przestrzeń kontaktu na wielu płaszczyznach: cywilizacyjnej i religijnej na południu i wschodzie, ideologicznej - chwilowo nieistniejącej - w centrum, czego symbolem był mur berliński, czy polityczno-gospodarczej, na pewnych odcinkach pokrywającej się z dawną ideologiczną, rozumianej jako zewnętrzna granica Unii Europejskiej. Wydaje się, że potencjał rozwoju turystyki na tak wyraźnie zarysowanych pograniczach jest wyjątkowo duży, tymczasem doświadczenia w tej kwestii są niewielkie i dość nieoczywiste - jeśli odnotujemy, że jednym z prymusów wykorzystania potencjału granicy jest Finlandia. Tanja Löytynoja, analizując rozwój funkcji turystycznych na granicy fińsko-rosyjskiej, zwraca uwagę na trzy typy konstruktu budowanego w oparciu o jej atrakcyjność: unaocznienie i przedstawienie, opowiedzenie i jej doświadczenie (2007). Löytynoja zwraca uwagę, że produkty turystyczne związane z granicą towarzyszą innym elementom atrakcyjności, jak np. historii wydarzeń wojennych (m.in. bitwy na drodze Raate) czy ciekawostce geograficznej w postaci najbardziej na wschód wysuniętego punktu Unii Europejskiej ${ }^{1}$. Tworzenie produktu turystycznego przyjmuje więc postać budowania małych, lokalnych muzeów, stawiania pamiątkowych obelisków, wykorzystania słupków granicznych czy infrastruktury towarzyszącej - jak chat z paleniskiem, parkingów itp. Równie istotne są dwa kolejne typy konstruktu. Historia opowiadana przez przewodników czy upowszechniana w postaci broszur pełni funkcję uzupełniającą, a szczególnie ciekawe i silnie przyciągające turystów wydaje się oferowane doświadczenie przekraczania granicy. Kilka lokalnych firm wyspecjalizowało się w organizowaniu różnych programów turystycznych opierających się na zainscenizowanym przekroczeniu granicy, kontroli paszportowej z udziałem rosyjskojęzycznych aktorów ubranych w mundury, wzbogaconych stereotypowymi elementami rosyjskiej kultury, np. piciem wódki w ziemiance. Taka forma przedsiębiorczości rozwinęła się nawet w gminach (kuntach) niegraniczących z Rosją. Dzięki temu granica stała się swoistym miejscem doświadczeń (a place of experiences) (Cresswell, 2004) oddziałującym na turystów mocniej niż fizyczne przejawy obecności granicy.

Południowa, lądowa granica Unii Europejskiej - pomijając departamenty zamorskie Francji ogranicza się do dwóch hiszpańskich przyczółków w Maroku (Ceuta i Melilla) oraz granicy turecko-bułgarskiej, turecko-greckiej oraz dość kuriozalnej turecko-cypryjskiej. Kuriozalnej, ponieważ mimo że Cypru Północnego nikt poza samą Turcją nie uznaje, funkcjonowanie granicy pozostaje niezaprzeczalnym faktem. W wymienionych przypadkach granica ma ograniczone możliwości stania się główną atrakcją turystyczną, jednak dzięki swej funkcji oddzielającej dwa odmienne światy może stanowić element uzupełniający w aktywności turystycznej, szczególnie dla turystów poszukujących alternatywy dla śródziemnomorskich plaż i antycznych zabytków. Dobrym tego zwiastunem jest informacja o granicy hiszpańsko-marokańskiej zaczerpnięta z Lonely Planet, niekwestionowanego lidera wśród anglojęzycznych przewodników, mającego 1/4 globalnego rynku (Tegelberg, 2010) i będącego swoistą „biblią”, czasem wręcz traktowaną dogmatycznie, dla wielu turystów:

„Ceuta jest prawdziwą niespodzianką dla przybywających tu ze strony Maroka. Podobnie jak niegdyś w Berlinie Zachodnim, granica oddzielająca oba kraje wygląda jak wielki eksperyment społeczny wymyślony przez rywalizujące ze sobą systemy polityczne. Pozostawiając za sobą żebraków i naganiaczy, przekracza się strefę graniczną - 400 metrów ziemi niczyjej z nieregularnie rozmieszczonymi barykadami (część kosztującego $30 \mathrm{mln} €$ ogrodzenia wzniesionego

${ }^{1}$ Po akcesji Cypru w 2004 r. punkt utracił swoje znaczenie, ale na podstawie bilateralnej umowy fińsko-cypryjskiej dalej za taki uchodzi. 
przez UE w celu zapobiegania nielegalnej imigracji) - aby znaleźć się w migoczącym światłami świecie kultury hiszpańskiej, świecie zadbanych placów, pięknych budynków i barów tapas otwartych do późnych godzin nocnych. Samo to doświadczenie jest warte podróży." (http:// www.lonelyplanet.com/morocco...)

Europejski system nadzorowania granic Eurosur - którego zadaniem jest ograniczanie niekontrolowanego przepływu migrantów do Unii Europejskiej, a który w Ceucie czy Melilli przyjmuje formę podwójnych, 6-metrowej wysokości zasieków zwieńczonych drutem kolczastym - jest powszechnie krytykowany m.in. za podkreślanie różnic społecznych i kulturowych między Unią Europejską a krajami sąsiednimi czy tzw. konteneryzację przestrzeni (spatial containerisation) (Boedeltje, Van Houtum, 2008). Tworzone są w jego kontekście metafory nawiązujące do podziału świata na linii Północ - Południe, jak np.: ,,nowy mur wstydu”, ,złota kurtyna" czy Forteca Europa (Driessen, 1996). Niemniej obie hiszpańskie enklawy, mimo kontrowersji narosłych wobec tego projektu, mają możliwości, aby ten niecodzienny potencjał wykorzystać, podobnie jak to zaczyna czynić Cypr.

Granica od 1974 r. oddzielająca Republikę Cypru od Cypru Północnego, będącego pod jurysdykcją turecką, dzieli również samą jego stolicę. Przejście graniczne w Nikozji, na ulicy Ledra, jest według portalu tripadvisor 10. największą atrakcją stolicy (www.tripadvisor.co.uk/ Attraction...). Co więcej, na 11 piętrze pobliskiego wieżowca Shacolas Tower mieści się Muzeum - Obserwatorium Ledra (piąte miejsce w wymienionym rankingu) umożliwiające zapoznanie się z historią podziału wyspy oraz obserwację przez lornetki struktury całego miasta. Cypryjska granica, podobnie jak hiszpańsko-marokańska, symbolicznie oddziela od siebie huntingtonowskie cywilizacje, co dodatkowo znajduje wyraz w symbolicznym znakowaniu przestrzeni, widocznym m.in. w usypanych na wzgórzach flagach Północnego Cypru z centralnie umieszczonym półksiężycem, co może stanowić dodatkową atrakcję.

Również inne granice cywilizacyjne, stanowiące fizyczną barierę dla kontaktu między obu stronami, powoli stają się atrakcją turystyczną, wbrew woli ich ,pprojektantów”. Nasilenie polityki ograniczającej nielegalne przepływy migracyjne z Meksyku do USA za prezydentury George'a W. Busha skutkowało rozwojem systemu ochrony granic, zbliżonego do Eurosur. Mury, zasieki, drut kolczasty, zaorana ziemia, monitoring i inne elementy infrastruktury granicznej przyciągają całe rzesze amatorów tego typu atrakcji.

Bardziej subtelną formę przybiera oddolne i niezamierzone tworzenie walorów turystycznych na pograniczu izraelsko-palestyńskim. Niesławny mur wybudowany przez stronę izraelską, mocno krytykowany za tworzenie wrażenia gettyfikacji Palestyńczyków, stał się podstawą licznych akcji artystycznych w postaci m.in. całej serii murali wykonanych przez Banksy’ego.

\section{Podsumowanie i dyskusja}

Znaczenie turystyczne granic państwowych, poza nielicznymi studiami przypadków, jest wciąż słabo zbadane (Timothy, 2000a). Poza niewielkim zainteresowaniem ze strony naukowców, może to wynikać również z faktu obiektywnych trudności z tego typu badaniami, rzadko bowiem motywacją turysty jest tylko sama granica. Ponadto trudno stwierdzić, kiedy „konsumpcja" tego produktu występuje. Przykładem może być spisana przez autora relacja Bartosza Trzewika z jego wyjazdu do Doniecka w sierpniu 2014 r., dla którego ,przeżycie granicy” było jednym z elementów wyjazdu, czego statystyki nie są w stanie wychwycić:

„Pojechałem do Doniecka, aby naocznie przekonać się, jak wygląda konflikt we wschodniej Ukrainie [...]. Granica między terenami kontrolowanymi przez Ukrainę a tymi opanowanymi przez separatystów była jednym z celów wyjazdu. [...] Myślę, że jest to miejsce interesujące, szczególnie dla mężczyzn. Prowizoryczne umocnienia, kontrola bagażu, a zwłaszcza baterie 
dział skierowane w stronę wroga wraz z częstą wymianą ognia słyszaną w oddali sprawiają, iż odnosi się wrażenie, że wjeżdża się do zupełnie innego świata".

Granica traktowana jako strefa kontaktu wydaje się mniej atrakcyjna niż jako linia oddzielająca (Timothy, 1995). Przytoczone przykłady dowodzą, że nie w pełni uzasadniona jest teza Erikksona (1979), który twierdził, że poziom atrakcyjności obszarów granicznych zależy od środowiska naturalnego, społecznego i kulturowego w pobliżu granicy oraz stopnia swobody lub trudności w jej przekraczaniu. Przykłady wykorzystania atrakcyjności turystycznej granic pokazują, że to granice cywilizacyjne oraz mocno różnicujące granice ekonomiczne zdają się mieć największy potencjał rozwojowy. Granice pomiędzy Koreą Południową a KRLD, indyjsko-pakistańska, amerykańsko-meksykańska czy izraelsko-palestyńska są tego najlepszym dowodem, choć nie zawsze idzie za tym kreowanie produktu turystycznego. Mimo że w ostatnich dekadach zmienia się rola granic w kierunku obszarów kontaktu i współpracy (Häkli, Kaplan, 2002) - co szczególnie widać na przykładzie zacieśniania współpracy w ramach Unii Europejskiej - wydaje się, że ich potencjał rozwojowy, również w krajach europejskich, nie jest w pełni wykorzystany. Z jednej strony dotyczy on południowych granic Unii Europejskiej, z drugiej - jej granicy wschodniej i dawnej żelaznej kurtyny, mających duże znaczenie symboliczne (Paasi, 1996; Medvedev, 1999), których wykorzystanie turystyczne można by istotnie wzbogacić o elementy historyczne, jak w przypadku działania instytucji i przedsiębiorców niemieckich czy fińskich. Na odcinkach dawnej granicy polsko-radzieckiej zachowało się wiele fragmentów tzw. sistiemy, która poza dużymi walorami poznawczymi stanowiłaby doskonałą kanwę do edukacji historycznej. Przykład fiński pokazuje, że nie jest trudno wykreować popyt na tego typu produkt. Dodatkowym argumentem za ich wykorzystaniem może być fakt, że na obszarach peryferyjnych granice siłą rzeczy stanowią istotny czynnik rozwoju regionów (Butler, 1996; Saarinen, 2003), w tym kontekście niewykorzystany. Tymczasem doświadczenia europejskie pokazują, że o ile granice reliktowe stanowią ważny element aktywizacji turystycznej regionów, czego przykładem są Mur Hadriana i mur berliński, a może w przyszłości również trójkąt trzech cesarzy (Padło, 2014), o tyle wykorzystanie obecnych granic występuje w bardzo ograniczonej skali.

Również występujące w Europie enklawy i trójstyki, odznaczające się naturalną predyspozycją do przyciągania turystów z uwagi na swoją nietypowość, są relatywnie rzadko wykorzystane. Jest to o tyle dziwne, że przypadek Baarle Hertog w oczywisty sposób prezentuje zalety wypromowania swojej niezwykłości.

Dzisiejszy turysta coraz częściej poszukuje bardziej alternatywnych form dla swojej aktywności. Granica wywołująca nierzadko ekscytację, oferująca różnorodność kulturową, a czasem nawet pewną dozę niebezpieczeństwa wpisuje się w dynamicznie rozwijające się formy turystyki jak special interest tourism czy political tourism. Paradoksalnie więc granice pełniące funkcje zaścianków czy nawet dezintegracyjne (Moraczewska, 2008) mogą tych turystów do siebie przyciągnąć.

Mimo wspomnianych ograniczeń badawczych, stanowiących niedoskonałość również tej pracy, celowym wydaje się podjęcie szerszych i bardziej precyzyjnych badań na temat możliwości wykorzystania granic do rozwoju opartej o nie funkcji turystycznej. Więckowski (2010) zauważa, że w Polsce praktycznie nie ma atrakcji turystycznych stworzonych przez człowieka na samej granicy. Nie jest to do końca precyzyjne, gdyż później sam zwraca uwagę na cztery zagospodarowane turystycznie trójstyki - choć w ograniczony sposób. Niemniej przytoczone przykłady pokazują, że potencjał polskich granic jest pod tym względem niewykorzystany, co w kontekście braku badań na ten temat otwiera nowe pole badawcze. 


\section{Literatura \\ References}

Baczwarow, M., Suliborski, A. (2002). Kompendium wiedzy o geografii politycznej i geopolityce. Warszawa-Łódź: Wydawnictwo Naukowe PWN.

Bański, J. (2010). Granica w badaniach geograficznych. Przeglą Geograficzny, 82, 4, 489-508.

Biliński, J., Sawaryn, D. (red.). (2003). Turystyka czynnikiem integracji międzynarodowej. Rzeszów: Wydawnictwo Wyższej Szkoły Informatyki i Zarządzania w Rzeszowie.

Blacksell, M. (2008). Geografia polityczna. Warszawa: PWN.

Boedeltje, F., van Houtum, H. (2008). The abduction of Europe: A plea for less 'unionism'

and more Europe. Tijdschrift voor Economische en Sociale Geografie, 99, 361-365.

Boyes, R., Cywiński, P. (2003). Sezon na Europę. Warszawa: Czytelnik.

Butler, R.W. (1996). The Development of Tourism in Frontier Regions: Issues and Approaches. W: Y. Gradus, H. Lithwick (red.), Frontiers in Regional Development. Lanham: Rowman \& Littlefield, 213-229.

Butler, R.W. (2002). The Development of Tourism in Frontier Regions: Issues and Approaches. W: S. Krakover, Y. Gradus (red.), Tourism in Frontier Areas. Oxford: Lexington Books.

Cresswell, T. (2004). Place: a short introduction. Malden: Blackwell Publishing.

Driessen, H. (1996). At the edge of Europe: Crossing and marking the Mediterranean divide. W: L. O'Dowd, T.M.Wilson (red.), Borders, Nations and States. Aldershot: Ashgate Publishing Company.

Eriksson, G.A. (1979). Tourism at the Finnish-Swedish-Norwegian borders. W: G. Gruber, H. Lamping, W. Lutz, J. Matznetter, K. Vorlaufer (red.), Tourism and Borders: Proceedings of the IGU Group, Geography and Tourism Recreation. Frankfurt: Institut fur Wirtschafts-und Sozialgeographie der Johann Wolfgang Geothe Universitat, 151-162.

Felsenstein, D., Freeman, D. (2002). Gambling on the Border: Casinos, Tourism Development, and the Prisoners' Dilemma. W: S. Krakover, Y. Gradus (red.), Tourism in Frontier Areas. Oxford: Lexington Books.

Häkli, J., Kaplan, D.H. (2002). Learning from Europe? Borderlands in Social and Geographical Context. W: D.H. Kaplan, J. Häkli (red.), Boundaries and Place. European Borderlands in Geographical Context. Lanham: Rowman \& Littlefield Publishers.

Heffner., K. (2002). Efektywność współpracy w euroregionach na granicy polsko-czeskiej. W: A. Stasiak (red.), Euroregiony wschodniego pogranicza - założenia i osiagnięcia. Białystok: Wyd. Wyższej Szkoły Ekonomicznej w Białymstoku, 255-268.

Huntington, S. (2007). Zderzenie cywilizacji. Warszawa: Muza.

Jacobs, F. (2014, 30 września). Peacocks at Sunset. New York Times. Pozyskano z http://opinionator.blogs. nytimes.com/2012/07/03/peacocks-at-sunset/

Kałuski, S. (1993). Turystyka kwalifikowana jako czynnik rozwoju regionalnego obszarów przygranicznych Polski. Warszawa: Fundacja im. Friedricha Eberta.

Kałuski, S. (2006). Border tripoints as transborder cooperation regions in Central and Eastern Europe. W: J. Kitowski (red.), Regional trans-border co-operation in countries of Central and Eastern Europea balance of achievements. Warszawa: Geopolitical Studies, 14, 27-36.

Kitowski, J. (red.). (1996). Problemy regionalnej współpracy transgranicznej. Rozprawy i Monografie Wydziału Ekonomicznego, Uniwersytet Marii Curie-Skłodowskiej - Filia w Rzeszowie, 10.

Kitowski, J. (red.). (1998). Czynniki i bariery regionalnej wspótpracy transgranicznej - próba syntezy. Rozprawy i Monografie Wydziału Ekonomicznego, Uniwersytet Marii Curie-Skłodowskiej - Filia w Rzeszowie, 15.

Kitowski, J. (red.). (2006). Regional trans-border co-operation in countries of Central and Eastern Europe - a balance of achievements. Warszawa: Geopolitical Studies, 14.

Komornicki, T. (1999). Granice Polski. Analiza zmian przenikalności w latach 1990-1996. Geopolitical Studies, 5. Warszawa: IGiPZ PAN.

Korea National Tourism Organization (2004). Master plan for development of peace tourism belt in the $D M Z$ and its vicinity. Seoul: Government Printer. 
Lee, T.J., Kang, E-J. (2013). Living with war. The Korean truce. W: R. Butler, W. Suntikul (red.), Tourism and War: Contemporary Geographies of Leisure, Tourism and Mobility. Routledge, 121-131.

Light, D. (2000). Gazing on communism: Heritage tourism and post-communist identities in Germany, Hungary and Romania. Tourism Geographies: An International Journal of Tourism Space, Place and Environment, 2, 2, 157-176.

Löytynoja, T. (2007). National Boundaries and Place-making in Tourism: Staging the Finnish-Russian Border. Nordia Geographical Publications, 36, 4, 35-45.

Lysenko, I., Besançon, C., Savy, C. (2007). 2007 UNEP-WCMC Global List of Transboundary Protected Areas. Pozyskano z: http://www.tbpa.net/page.php?ndx=78, dostęp: 30 września 2014.

Medvedev, S. (1999). Across the line: Borders in post-Westphalian landscapes. W: H. Eskelinen, I. Liikanen, J. Oksa (red.), Curtains of iron and gold. Reconstructing borders and scales of interaction. Aldershot: Ashgate, 43-56.

Mehdi, S.S. (2005). A Peace Museum on the Wagah Border. South Asian Journal, 10, 116-126.

Mogiła, Z., Zaleski, J., Zathey, M. (2011). Wykorzystanie przygranicznego położenia terenów znajdujących się w zachodniej części Polski dla rozwoju społeczno-gospodarczego. Wrocław.

Moraczewska, A. (2008). Transformacja funkcji granic Polski. Lublin: Wydawnictwo UMCS.

Mync, A., Szul, R. (red.). (1999). Rola granicy i wspótpracy transgranicznej w rozwoju regionalnym i lokalnym. Warszawa: Europejski Instytut Rozwoju Regionalnego i Lokalnego UW.

Otok, S. (2009). Geografia polityczna. Warszawa: PWN.

Paasi, A. (1996). Territories, Boundaries and Consciousness: The Changing Geographies of the Finnish-Russian Border. Chichester: Wiley.

Paasi, A., Raivo, P.J. (1998). Boundaries as barriers and promoters: Constructing the tourist landscapes of Finnish Karelia. Visions in Leisure and Business, 17, 3, 30-45.

Padło, T. (2014). Koniec świata. Kraków: Universitas.

Potocki, J. (2009). Funkcje turystyki w ksztaltowaniu transgranicznego regionu górskiego Sudetów. Wrocław: Wydawnictwo WTN.

Prescott, J.R.V. (1965). Geography of Frontiers and Boundaries. London: Hutchinson University Library.

Prescott, J.R.V. (1987). Political Frontiers and Boundaries. London: Unwin Hyman.

Redclift, M.R. (2006). Frontiers: Histories of Civil Society and Nature. Cambridge: MIT Press.

Ryden, K.C. (1993). Mapping the Invisible Landscape: Folklore, Writing, and the Sense of Place. Iowa City: University of Iowa Press.

Rykiel, Z. (2006). Podstawy geografii politycznej. Warszawa: PWE.

Saarinen, J. (2003). The Regional Economics of Tourism in Northern Finland: The Socio-economic Implications of Recent Tourism Development and Future Possibilities for Regional Development. Scandinavian Journal of Hospitality and Tourism, 3, 91-113.

Sobczyński, M. (2006). Geografia granic i pograniczy w badaniach łódzkiego ośrodka geograficznego. Folia Geographica-Oeconomica, Acta Geographica Lodziensia, 7, 19-36.

Squire, S.J. (1994). Accounting for cultural meanings: the interface between geography and tourism studies re-examined. Progress in Human Geography, 18, 1, 1-16.

Szul, R. (1999). Rola granicy w gospodarce - próba ujęcia teoretycznego. W: A. Mync, R. Szul (red.), Rola granicy $i$ wspótpracy transgranicznej w rozwoju regionalnym i lokalnym. Warszawa: Europejski Instytut Rozwoju Regionalnego i Lokalnego UW, 227-232.

Tegelberg, M. (2010). Hidden sights: Tourism, representation and „Lonely Planet Cambodia”. International Journal of Cultural Studies, 13(5), 491-509.

Timothy, D.J. (1995). Political boundaries and tourism: borders as tourist attractions. Tourism Management, 16, 7, 525-532.

Timothy, D.J. (1996). Small and isolated: the politics of tourism in international exclaves. Acta Turistica, $8(2), 99-115$.

Timothy, D.J. (2000a). Tourism in the borderlands: economic development and cross-frontier cooperation. W: S. Krakover, Y. Gradus (red.), Tourism in Frontier Regions. Baltimore: Lexington Books.

Timothy, D.J. (2000b). Borderlands: An Unlikely Tourist Destination? IBRU Boundary and Security Bulletin, 57-65. 
Timothy, D.J., Wall, G. (2001). Tourism and Political Boundaries. London: Routledge.

Vinokurov, E. (2007). A Theory of Enclaves. Lanham: Lexington Books.

Więckowski, M. (2010). Turystyka na obszarach przygranicznych Polski. Warszawa: IGiPZ PAN.

Więckowski, M. i in. (2012). Pogranicze polsko-stowackie. Dostępność transportowa a turystyka. Warszawa: IGiPZ PAN.

Zhao, X. (1994). Barter tourism along the China-Russia border. Annals of Tourism Research, 24, 401-403.

\section{Źródla interentowe}

www.lonelyplanet.com/morocco/the-mediterranean-coast-and-the-rif/ceuta-sebta, 2014, 30 września. www.magnumphotos.com/C.aspxVP3=SearchResult\&ALID=2TYRYDA8TPED, 2014, 30 września. www.tripadvisor.co.uk/Attraction_Review-g190383-d2067161-Reviews-Ledra_Street_Crossing_Point-

-Nicosia_Nicosia_District.html, 2014, 30 września.

Dz.U. 1990 nr 78, poz. 461.

Tomasz Padło, dr, Uniwersytet Pedagogiczny im. Komisji Edukacji Narodowej w Krakowie, Instytut Geografii, Zakład Geografii Społeczno-Ekonomicznej.

W pracy naukowej zainteresowany postrzeganiem przestrzeni, geografią granic, również reliktowych oraz geografią społeczną Europy Środkowej. Współzałożyciel Fundacji Bezgranica zajmującej się promocją wiedzy za pomocą sztuk wizualnych.

Tomasz Padło, PhD, Pedagogical University of Cracow, Institute of Geography, Department of Socio-Economic Geography.

His field of interest focuses on the perception of geographical space, geography of boundaries, including relict borders and social geography of Central Europe. Co-founder of the Bezgranica Foundation involved in the promotion of knowledge through visual arts.

Adres/Address: Uniwersytet Pedagogiczny im. Komisji Edukacji Narodowej w Krakowie Instytut Geografii

ul. Podchorążych 2

30-084 Kraków, Polska

e-mail: tpadlo@up.krakow.pl 